Article

\title{
Econometric Modeling of SME Performance. Case of Romania
}

\author{
Ioan Batrancea ${ }^{1, *}$, Ioan-Dan Morar ${ }^{2}$, Ema Masca ${ }^{3}$, Sabau Catalin ${ }^{1}$ and Liviu Bechis ${ }^{4}$ \\ 1 Faculty of Economics and Business Administration, Babeş-Bolyai University, 58-60 Teodor Mihali Str., \\ Cluj-Napoca400591, Romania; cata_sab@yahoo.com \\ 2 Faculty of Economics, University of Oradea, 1-5 Armatei Romane Str., Oradea 410087, Romania; \\ imorar@uoradea.ro \\ 3 Faculty of Economics, Juridical and Administrative Sciences, Petru Maior University, 69 Livezeni Str., \\ Targu-Mures 540566, Romania; ema.masca@ea.upm.ro \\ 4 Faculty of Economics, Computer Science and Engineering, "Vasile Goldis” Western University of Arad, \\ 86 Liviu Rebreanu Str., Arad 310414, Romania; liviubichis1960@yahoo.com \\ * Correspondence: ioan.batrancea@econ.ubbcluj.ro; Tel.: +407-4477-1329; Fax: +402-6441-2570
}

Received: 12 November 2017; Accepted: 9 January 2018; Published: 17 January 2018

\begin{abstract}
In the present study, we analyzed the financial equilibrium factors that have a major impact on SME financial performance, as this performance is considered to have played a pivotal role in Romania's recovery from the economic crisis. Thus, we built econometric models based on return on assets and return on sales in five economic sectors, i.e., pharmaceuticals, furniture manufacturing, leather garment factories, software firms and textile factories. We show how the enterprises' performance was influenced by the independent variables of the equilibrium: fixed assets, current assets, inventory, receivables, equity and liabilities. The results indicate that return on assets is influenced by the current assets ratio and the inventory ratio in all models, as well as by the equity-to-total liabilities ratio in $80 \%$ of the models. We also notice that assets ratios have the highest influence on performance evaluation, namely inventory ratio in all models and current assets ratio in $87.5 \%$ of the models. In addition, liabilities ratios influence performance as follows: equity-to-total liabilities ratio in $80 \%$ of the models and total debt-to-assets ratio in $35 \%$ of the models.
\end{abstract}

Keywords: sales; assets; debt-to-equity; total debt-to-assets

\section{Introduction}

SMEs play an essential role in the global economy and they are a source of entrepreneurial skills, innovation and job creation, a factor of social and economic cohesion both in the European Union (EU) and in the United States (US). In the EU, which currently comprises 28 member states, approximately 23 million small and medium enterprises (SMEs) provide around 75 million jobs and represent $99 \%$ of total enterprises. The goal of each of these numerous economic entities is to obtain profit. The last two decades, characterized by dramatic changes at technical, economic, social, informational, educational, cultural and political levels, highlight the fundamental role of small and medium enterprises sector for the development of a modern, dynamic, knowledge-based economy. This sector plays an essential role in the European economy. The EU experience shows that small businesses create new jobs, substantially contribute to the gross domestic product and stimulate exports, thus supporting macroeconomic stability and growth. SMEs have a flexible development strategy, aiming at responding rapidly to the competitiveness of international markets and adapting to cyclical changes in the global economy. Moreover, many of the recent inventions are provided by small and medium enterprises. Namely, dynamic units in hi-tech areas such as informatics, electronic commerce, genetics or biotechnology are or have recently been developed by small and medium enterprises. 
SMEs are particularly important in supporting social and regional development, thus having a valuable and productive approach at all levels of responsibility. These economic agents represent active and dynamic factors of a functional market economy. Having a significant importance at economic, social and political levels, SMEs are the basis of a modern society. Moreover, economic realities demonstrate the existence of a strong complementary relationships between large companies and SMEs.

The aim of this study is to show that an increase in the economic efficiency of SMEs can be generated via decreasing receivables, inventories and total debts, via increasing equity or via both approaches. The objective of the paper consists in identifying to what extent return on assets and return on sales are influenced by factors such as fixed assets ratio, current assets ratio, inventory ratio, receivables ratio, equity-to-total liabilities ratio, total debt-to-assets ratio and debt-to-equity ratio. The novelty of the paper resides in the fact that, to the best of our knowledge, we conduct the first empirical research regarding SME performance in five industries based on balance sheet ratios. As a contribution, we show that return on assets and return on sales are influenced by the abovementioned factors. Another contribution of the paper is that in both performance models for all five industries, the inventory ratio negatively influence return on assets and return on sales. Finally, we show that debt-to-equity ratio does not significantly influence the performance of 1233 SMEs in the five sectors of activity.

The reminder of the paper has the following structure. Literature review highlights relevant studies tackling the problem of performance within the five industries. Method and results presents the research hypotheses, the proposed econometric models together with their estimated outcomes. The final part emphasizes the main results of the study, limitations and avenues for future research.

\section{Literature Review}

SMEs contribute to raising the living standards of a society by stimulating economic activity, creating new jobs and diversifying products offered to consumers. Business development creates jobs, contributing in turn to improving health, educational and social services. These are few of the reasons for which improved business profitability of SMEs should represent a priority for any government policy. Over time, Romania's EU integration process was facilitated by a functioning market economy, which involves finalizing the privatization program, improving the business environment, reforming labor and capital markets and, most importantly, developing small and medium enterprises. The rapid and widespread development of small businesses that create jobs for the redundant staff in the public sector was also a precondition for restructuring and privatizing Romanian economy.

Previous studies on performance can be categorized in five main areas, as follows: growth and performance, capital market and profitability, working capital and performance, cash flow and earnings, capital structure and profitability. The relationship between performance and the financial position of SMEs has been analyzed in many studies. Most of these empirical studies have focused on profitability and growth. Hence, Lu and Beamish [1] examine differential effects of internationalization strategies on two dimensions of SME performance, namely growth and return on sales. Using a sample of 164 Japanese SMEs, they find that operating activity positively impacts on growth, while it negatively impacts on profitability. In their study on the profitability of Swedish micro-firms, Salman and Yazdanfar [2] investigate the degree to which firm size, sales growth, productivity, lagged profits, asset turnover and firm's age influence the profitability of Swedish micro-firms. Results indicate that sales growth and productivity positively impact on the profitability of micro-firms, whereas the variable firm size negatively impact on the profitability of micro-firms. Moreover, they report that growth and productivity are directly linked in all economic sectors, excepting the metal sector. McMahon [3] studies how financial reporting practices impact on business growth and performance outcomes using a sample pool of small and medium-sized enterprises operating within the Australian manufacturing industry. The study reports significant bivariate associations established between the extent and frequency of financial reporting and specific measures of performance and growth. Farah and Supartika [4] focus on 
the factors influencing profitability, such as firm size, firm age, growth, lagged profitability, productivity and industry affiliation using a sample pool of SMEs listed on Indonesia Stock Exchange. Their results indicate that factors such as firm size, growth and lagged profitability negatively impact on profitability, while factors such as productivity and industry affiliation positively influence profitability.

Furthermore, most studies analyzing company performance focus on company profitability and capital market. Mikkola et al. [5] show that profitability varies significantly among smallest enterprises. In numerous situations, enterprise capital is generally spent, therefore leaving many enterprises and businesses exposed to bankruptcy risk. Gedajlovic et al. [6] estimate the impact of equity ownership of financial institutions on company performance in Japan for the period 1986-1991. They find that such ownership is reflected in the balance sheet and it is positively associated with company performance. Goddard et al. [7] use panel data econometrics to analyze the factors influencing the profitability of manufacturing and service sector companies from Belgium, France, Italy and the UK, during the period 1993-2001. Results indicate a negative relationship between size and profitability, a positive relationship between market share and profitability, but also a negative relationship between gearing ratio and profitability. Another finding is that firms with higher liquidity appear to be more profitable. Fitzsimmons et al. [8] investigate the relationship between growth rates and profitability using a considerable sample pool of Australian firms and find no evidence of a significant relationship between the two variables.

Managing adequately the firm's working capital has important effects on company profitability. Therefore, it is important to understand that working capital has a considerable influence on SME profitability. Knauer and Wöhrmann [9] show that the management of accounts receivable and the management of inventory positively impacts on company profitability. Yet, the impact of the management of accounts payable on company profitability is governed by reverse causality. Singhania et al. [10] analyze the relationship between working capital and profitability using cash conversion cycle as a proxy for working capital management and gross operating profit as a proxy for company profitability. Results report a negative relationship between cash conversion cycle and profitability, thus making it necessary to reduce the number of days for accounts receivable and to increase the number of days for accounts payable. Yasir et al. [11] aim at examining the relationship between cash conversion cycle and performance proxied by return on assets, using a sample pool of 16 firms operating in the cement industry in Pakistan, analyzed over a six-year period. They also investigate the relationship between receivables collection period, inventory conversion period and payables deferral period, on one side, and profitability, on the other side.

Nobanee et al. [12] tackle the relationship between the cash conversion cycle of a firm and profitability using the analysis of dynamic panel data on a sample of Japanese firms analyzed in the period 1990-2004. Similarly, Ebben and Johnson [13] analyze the connection between cash conversion cycle and liquidity levels, invested capital, and performance by using a sample of 879 small manufacturing firms and 833 small retail firms from the United States. They find that firms with productive cash conversion cycles register higher liquidity, higher returns, fewer debts and lower levels of equity financing. Moreover, according to their results, small entity owners and managers may be less proactive in the process of managing cash conversion cycles. Moss and Stine [14] analyze the cash conversion cycle of retail firms with a particular emphasis on cash flow and they report that the length of the cash conversion cycle is negatively linked to cash flows. Soenen [15] examines 20 industries over a 20-year period and offers empirical evidence for a negative relationship between the net trade cycle of a company and profitability (computed as return on total assets). According to the results, shorter net trade cycles are generally associated with higher profitability and vice-versa. Muscettola [16] examines the impact of cash conversion cycle on profitability on a sample of Italian manufacturing firms. Results reveal a significant relationship between average receivables and profitability, therefore indicating that shortening cash conversion cycles leads to higher profitability (EBITA on net sales). Baños-Caballero et al. [17] analyze the link between working capital and profitability on a Spanish SME sample pool. Their results indicate the existence of a concave relationship between working 
capital level and profitability, meaning that Spanish SMEs register optimal working capital levels maximizing profitability.

Öner [18] tests the relationship between working capital and profitability on a sample of 110 manufacturing firms listed on Borsa Istanbul, analyzed over the period of 2005-2014. Findings indicate that working capital negatively impacts on firm profitability, hence suggesting that firms could increase profitability by minimizing cash conversion periods. Otuya and Eginiwin [19] examine the effect of inventory management on profitability of SMEs on the Nigerian market. Using a multiple regression analysis, they show that inventory turnover has a positive influence on financial performance. According to their results, there is a negative relationship between inventory conversion period and profitability, while there is no relationship between inventory leanness and profitability. Using a sample of 100,000 firms from 15 EU countries analyzed during the period 1999-2003, Bou and Sattora [20] find considerable differences among countries, despite the partial integration of their economies.

The cash conversion cycle is an important tool from several points of view: its connection with working capital and profit, the connection with value added, the connection with liquidity or company size. In this regard, Andone and Gaban [21] focus on the relationship between cash conversion cycle and performance investigated on a sample of Romanian SMEs, showing that cash conversion cycle influences return on assets, return on sales and return on equity.

A main problem of SMEs is the lack of cash, which affects their performance. Therefore, Major [22] reports that Hungarian firms manufacture below the feasible level, taking into account their input endowment. The under-production of such SMEs can be explained by an inefficient allocation of resources (i.e., labor in excess; lack of capital). Due to substantial inefficiencies, Hungarian firms amend their profitability by scaling down production and not by expanding it. In the field of financial analysis, forecasting often involves regressing one time series variable on another. Bezuidenhout et al. [23] estimate the relationship between earnings and cash flows. Martínez-Sola et al. [24] investigate the degree to which funds provided to customers influence profitability by using a sample of 11,337 Spanish manufacturing SMEs analyzed over the period 2000-2007. According to their results, managers can enhance company profitability by investing more in receivables. They also show that this effect is considerably larger if firms are more liquid, have a volatile demand and bigger market shares. Gaban [25] emphasizes that, in the financial reporting system, the balance sheet and profit and loss account are worldwide key elements, being part of recurring financial reporting, although the cash flow statement is not mandatory in many countries (e.g., Germany, The Netherlands). For instance, in Japan, cash flow reporting is mandatory only for companies listed on the stock exchange market. Using financial analysis techniques focusing on ratios such as return on equity and return on assets, Isberg and Pitta [26] analyze the results of two distinct strategies targeting brand equity growth. Csegedi et al. [27], Moscviciov et al. [28], Gaban [29], Serrasqueiro and Maçãs Nunes [30] also tackle the topic of performance assessment through various lenses.

Many studies focused on SME performance have tackled capital structure. Thus, Abeywardhana [31] investigates how capital structure influences the profitability of non-financial SMEs in the UK over the period 1998-2008. Results indicate that capital structure (especially long-term debt to total assets ratio) negatively influences profitability and that firm size positively determines profitability. Fu et al. [32] analyze the factors influencing financial risk of Chinese SMEs listed on the Shenzhen Stock Exchange by employing the Alexander Bathory model. In their view, there is a negative link between financial risk, on one side and current ratio, net profit margin, net asset ratio, fixed assets ratio, on the other side. Furthermore, financial risk is weakly linked to fixed asset turnover, total asset turnover, but it is not linked to debt structure, inventory turnover and accounts receivable turnover. Using a fixed effects regression model and a balanced panel data of 115 SMEs operating in Nigeria, Olutunla and Obamuyi [33] assess the relationship between profitability, bank loans, age and size of the business. Results show a significant interdependence between SME profitability and bank loans, but also a significant relationship between profitability and the size of the business. 
Olufunso et al. [34] analyze the degree to which debt usage influences SME profitability in the manufacturing sector. Results show a negative relationship between debt and profitability. Moreover, it is stated that SMEs have difficulties in contracting loans from commercial banks. Holz [35] finds that the low level of profitability registered by Chinese industrial state-owned enterprises is caused by a high level of the liability-asset ratio. SMEs have been recognized as a very important component within the Croatian economic sector. Using the ratios method, Žager et al. [36] emphasize the importance of equilibrium and performance indicators for SMEs in Croatia. Malhotra et al. [37] explain how data envelopment analysis (DEA) can be used as a decision support system to screen corporate bonds in order to obtain more benefits compared to traditional bond rating techniques. Lu et al. [38] measure nine profitability indicators for Chinese industrial firms over the period 1978-2006 and assess the impact of inflation on company profitability.

\section{Method and Results}

In order to highlight the economic and financial performance of SMEs in Romania, we analyzed the evolution of the return on assets (ROA) and the return on sales (ROS) as dependent variables and other ratios as independent variables on a sample pool comprising 1233 SMEs from five economic sectors (Table 1). The period of time analyzed is 2004-2008.

Table 1. The sample units according to the industries.

\begin{tabular}{cc}
\hline Industries & Number of SMEs \\
\hline Pharmaceutical & 34 \\
Furniture & 780 \\
Leather garment & 36 \\
Software & 346 \\
Textile & 37 \\
Total SMEs & 1233 \\
\hline
\end{tabular}

Source: www.listafirme.ro.

Definition of financial ratio variables

The independent variables considered in the study are the following:

- Fixed assets ratio (RFA), determined as the ratio of fixed assets to total assets;

- Current assets ratio (RCA), determined as the ratio of current assets to total assets;

- Inventory ratio (RI), determined as the ratio of inventories to current assets;

- Receivables ratio (RR), determined as the ratio of receivables to current assets;

- Equity-to-total liabilities ratio (REL), determined as the ratio of equity to total liabilities;

- Total debt-to-assets ratio (RDA), determined as the ratio of total debts to total assets;

- Debt-to-equity ratio (RDE), determined as the ratio of total debts to equity;

- Return on assets (ROA), determined as the ratio of net profit to total assets;

- Return on sales (ROS), determined as the ratio of net profit to total sales.

The software EViews 5.1 was used to perform the statistical analyses for the econometric models estimating ROA and ROS. The analyses are based on the Panel Seats Squares method, which is a specific method of generating equations for time series data.

Our empirical research is based on the following hypotheses:

Hypotheses 1. There is a linear dependence between return on assets (on one side) and fixed assets ratio, current assets ratio, inventory ratio, receivables ratio, equity-to-total liabilities ratio, total debt-to-assets ratio, debt-to-equity ratio (on the other side). 
Hypotheses 2. There is a linear dependence between return on sales (on one side) and fixed assets ratio, current assets ratio, inventory ratio, receivables ratio, equity-to-total liabilities ratio, total debt-to-assets ratio, the debt-to-equity ratio (on the other side).

The general form of the econometric equation is of the following type:

$$
\mathrm{F}\left(\mathrm{Y}_{\mathrm{i}, \mathrm{t}}\right)=\mathrm{a}_{0}+\mathrm{a}_{1} \times \mathrm{X}_{1, \mathrm{i}, \mathrm{t}}+\mathrm{a}_{2} \times \mathrm{X}_{2, \mathrm{i}, \mathrm{t}}+\mathrm{a}_{3} \times \mathrm{X}_{3, \mathrm{i}, \mathrm{t}}+\mathrm{a}_{4} \times \mathrm{X}_{4, \mathrm{i}, \mathrm{t}}+\mathrm{a}_{5} \times \mathrm{X}_{5, \mathrm{i}, \mathrm{t}}+\varepsilon_{\mathrm{i}, \mathrm{t}}
$$

where,

Y-represents the dependent variable;

$X$-represents the independent variable;

$\varepsilon$-represents the residuals;

i-refers to the firm's activity, taking values from 1 to 5 ;

$\mathrm{t}$-refers to the time period analyzed, namely 2004-2008; it takes values from 1 to 5 .

The model adequacy is given by the $R$-squared coefficient, i.e., the coefficient of multiple determination. The adjusted $R$-squared takes values from 0 to 1 and confirms or invalidates the adequacy of the chosen independent variables. The closer to 1 the value of this ratio is, the better the model explains the dependent variable. $F$-statistic explains the proportion in which the dependent variable is influenced by the independent variables. The value of the $t$ test of significance $(t$-statistic or Student test) must be significantly different from zero. In social sciences, $t$ values greater than 1.96 are admitted as significant.

Estimations of the return on assets and the return on sales models for each industry are presented in the following tables.

\subsection{Modeling Performance in the Pharmaceutical Industry}

Firstly, we built the return on assets econometric model for the SMEs active in the pharmaceutical industry as follows (Table 2).

Table 2. The econometric model of return on assets for pharmaceutical SMEs.

\begin{tabular}{|c|c|c|c|c|}
\hline \multicolumn{5}{|c|}{$\begin{array}{c}\text { Dependent Variable: ROA } \\
\text { Method: Panel Least Squares } \\
\text { Sample: } 2004-2008 \\
\text { Cross-Sections Included: } 34 \\
\text { Total Panel (Balanced) Observations: } 170\end{array}$} \\
\hline \multicolumn{5}{|c|}{$\mathrm{ROA}=\mathrm{C}(1)+\mathrm{C}(2) \times \mathrm{RCA}+\mathrm{C}(3) \times \mathrm{REL}+\mathrm{C}(4) \times \mathrm{RI}$} \\
\hline & Coefficient & Std. Error & $t$-Statistic & Prob. \\
\hline $\mathrm{C}(1)$ & -4.66 & 3.74 & -1.25 & 0.21 \\
\hline C(2) RCA & 0.24 & 0.05 & 5.28 & 0 \\
\hline C(3) REL & 0.17 & 0.04 & 4.53 & 0 \\
\hline $\mathrm{C}(4) \mathrm{RI}$ & -0.14 & 0.04 & -3.64 & 0 \\
\hline$R$-squared & 0.36 & \multicolumn{2}{|c|}{ Mean dependent variable } & 13.14 \\
\hline Adjusted $R$-squared & 0.35 & \multicolumn{2}{|c|}{ S.D. dependent variable } & 14.28 \\
\hline S.E. of regression & 11.51 & \multicolumn{2}{|c|}{ Akaike info criterion } & 7.75 \\
\hline Sum squared residual & $21,975.25$ & \multicolumn{2}{|c|}{ Schwarz criterion } & 7.82 \\
\hline Log likelihood & -654.48 & \multicolumn{2}{|c|}{ F-statistic } & 31.43 \\
\hline Durbin-Watson stat & 0.62 & \multicolumn{2}{|c|}{ Prob (F-statistic) } & 0 \\
\hline
\end{tabular}

The summarized regression results from the above table show that the multiple regression model is significant $(R$-squared $=0.36)$, meaning that $36 \%$ of the variation in the return on assets is explained by the independent variables, while $64 \%$ is explained by variables outside the model. Also, the F-statistic of 31.43 shows that predictors are significantly related to the dependent variable. The regression estimation reveals a positive relationship exist between ROA, RCA and REL and a 
negative relationship between ROA and RI. Namely, the coefficient of -0.14 indicates that a reduction in inventory leads to a performance improvement of 14 percent. In other words, when a company registers shorter periods in order to convert every transaction into cash, there will be more cash available and its performance will increase. We notice that ROA is influenced by current assets ratio (RCA), equity-to-total liabilities ratio (REL) and inventory ratio (RI). We thus observe that a 1000-unit rise in the RCA and REL values determines a 240-unit rise and a 170-unit rise in ROA.

The second econometric model applied to the same industry involves the return on sales (ROS) and is presented below (Table 3).

Table 3. The econometric model of return on sales for pharmaceutical SMEs.

\begin{tabular}{|c|c|c|c|c|}
\hline \multicolumn{5}{|c|}{ Dependent Variable: ROS } \\
\hline \multicolumn{5}{|c|}{$\begin{array}{c}\text { Method: Panel Least Squares } \\
\text { Sample: 2004-2008 } \\
\text { Cross-Sections Included: } 34 \\
\text { Total Panel (Balanced) Observations: } 170\end{array}$} \\
\hline \multicolumn{5}{|c|}{$\begin{array}{l}\text { White Diagonal Standard Errors and Covariance (d.f. Corrected) } \\
\text { ROS }=\mathrm{C}(1)+C(2) \times R C A+C(3) \times R I+C(4) \times R E L+C(5) \times R F A\end{array}$} \\
\hline & Coefficient & Std. Error & $t$-Statistic & Prob. \\
\hline $\mathrm{C}(1)$ & -97.5 & 59.8 & -1.63 & 0.10 \\
\hline C(2) RCA & 1.17 & 0.60 & 1.94 & 0.05 \\
\hline C(3) RI & -0.24 & 0.05 & -5.33 & 0 \\
\hline C(4) REL & 0.14 & 0.04 & 3.79 & 0 \\
\hline C(5) RFA & 1.06 & 0.60 & 1.75 & 0.08 \\
\hline$R$-squared & 0.32 & \multicolumn{2}{|c|}{ Mean dependent variable } & 13.53 \\
\hline Adjusted $R$-squared & 0.30 & \multicolumn{2}{|c|}{ S.D. dependent variable } & 15.30 \\
\hline S.E. of regression & 12.8 & \multicolumn{2}{|c|}{ Akaike info criterion } & 7.97 \\
\hline Sum squared residual & $27,040.38$ & \multicolumn{2}{|c|}{ Schwarz criterion } & 8.06 \\
\hline Log likelihood & -672.11 & \multicolumn{2}{|c|}{ F-statistic } & 19.08 \\
\hline Durbin-Watson stat & 0.87 & \multicolumn{2}{|c|}{ Prob (F-statistic) } & 0 \\
\hline
\end{tabular}

The analysis of the results indicates that the multiple regression model is significant. The value of $R$-squared $=0.32$ shows that $32 \%$ of the variation in the return on sales is explained by the independent variables, while $68 \%$ is explained by variables outside the model. In addition, the $F$-statistic value of 19.08 shows that the predictors are significantly related to the response variable. We notice that ROS establishes a direct relationship with RCA, REL, and RFA and an indirect relationship with RI. Thus, a rise of 1000 units in RCA, REL and RFA determines an increase in ROA of 1170, 140 and 1060 units, respectively. Moreover, a rise of 1000 units in RI determines a drop of 240 units in ROS.

\subsection{Modeling Performance in the Furniture Industry}

The following econometric model presented below refers to the return on assets ratio for the enterprises in the furniture industry (Table 4).

The analysis of the results indicates an average to low adjusted $R$-squared $=0.25$ and a high $F$-statistic (262.15), both suggesting that predictors are significantly related to the response variable. Therefore, the return on assets ratio is influenced by current assets ratio, equity-to-total liabilities ratio, total debt-to-assets ratio and inventory ratio. An increase of 1000 units in RCA, REL and RDA leads to an increased in ROA of 190 units, 320 units and 80 units. In addition, an increase of 1000 units in RI generates a drop of 100 units in ROA. 
Table 4. The econometric model of return on assets for SMEs in the furniture industry.

\begin{tabular}{|c|c|c|c|c|}
\hline \multicolumn{5}{|c|}{$\begin{array}{c}\text { Dependent Variable: ROA } \\
\text { Method: Panel Least Squares } \\
\text { Sample: } 2004-2008 \\
\text { Cross-Sections Included: } 780 \\
\text { otal Panel (Balanced) Observations: } 3900\end{array}$} \\
\hline \multicolumn{5}{|c|}{$\begin{array}{l}\text { White Diagonal Standard Errors and Covariance (d.f. Corrected) } \\
\text { ROA }=C(1)+C(2) \times R C A+C(3) \times R E L+C(4) \times R D A+C(5) \times R I\end{array}$} \\
\hline & Coefficient & Std. Error & $t$-Statistic & Prob. \\
\hline $\mathrm{C}(1)$ & -10.35 & 3.18 & -3.25 & 0 \\
\hline C(2) RCA & 0.19 & 0.01 & 15.64 & 0 \\
\hline C(3) REL & 0.32 & 0.04 & 7.29 & 0 \\
\hline C(4) RDA & 0.08 & 0.03 & 2.75 & 0.01 \\
\hline C(5) RI & -0.10 & 0.02 & -4.68 & 0 \\
\hline$R$-squared & 0.25 & \multicolumn{2}{|c|}{ Mean dependent variable } & 12.12 \\
\hline Adjusted $R$-squared & 0.25 & \multicolumn{2}{|c|}{ S.D. dependent variable } & 17.36 \\
\hline S.E. of regression & 15.03 & \multicolumn{2}{|c|}{ Akaike info criterion } & 8.26 \\
\hline Sum squared residual & $879,408.2$ & \multicolumn{2}{|c|}{ Schwarz criterion } & 8.27 \\
\hline Log likelihood & $-16,099.49$ & \multicolumn{2}{|c|}{$F$-statistic } & 262.15 \\
\hline Durbin-Watson stat & 1.01 & \multicolumn{2}{|c|}{ Prob (F-statistic) } & 0 \\
\hline
\end{tabular}

In the following, we present the econometric model estimating return on sales for the SMEs active in the furniture industry (Table 5).

Table 5. The econometric model of return on sales for SMEs in the furniture industry.

\begin{tabular}{|c|c|c|c|c|}
\hline \multicolumn{5}{|c|}{$\begin{array}{c}\text { Dependent Variable: ROS } \\
\text { Method: Panel Least Squares } \\
\text { Sample: } 2004-2008 \\
\text { Cross-Sections Included: } 780 \\
\text { Total Panel (Unbalanced) Observations: } 3900\end{array}$} \\
\hline \multicolumn{5}{|c|}{$\begin{array}{l}\text { White Diagonal Standard Errors and Covariance (d.f. Corrected) } \\
\qquad \text { ROS }=C(1) \times R C A+C(2) \times R E L+C(3) \times R I\end{array}$} \\
\hline & Coefficient & Std. Error & $t$-Statistic & Prob. \\
\hline C(1) RCA & 0.13 & 0.04 & 2.84 & 0 \\
\hline C(2) REL & 0.34 & 0.15 & 2.23 & 0.03 \\
\hline C(3) RI & -0.14 & 0.07 & -2.14 & 0.03 \\
\hline$R$-squared & 0.01 & \multicolumn{2}{|c|}{ Mean dependent variable } & 10.11 \\
\hline Adjusted $R$-squared & 0.01 & \multicolumn{2}{|c|}{ S.D. dependent variable } & 124.49 \\
\hline S.E. of regression & 124.06 & \multicolumn{2}{|c|}{ Akaike info criterion } & 12.48 \\
\hline Sum squared residual & $599,164.07$ & \multicolumn{2}{|c|}{ Schwarz criterion } & 12.49 \\
\hline Log likelihood & $-24,314.12$ & \multicolumn{2}{|c|}{$F$-statistic } & 10.04 \\
\hline Durbin-Watson stat & 2.45 & \multicolumn{2}{|c|}{ Prob (F-statistic) } & 0 \\
\hline
\end{tabular}

The results indicate a low value of the adjusted $R$-squared (0.01) and a convenient $F$-statistic value (10.04), showing that predictors are significantly related to the response variable. The regression estimation reveals that a significant positive relationship exists between RCA, REL, RI and ROS $(t=2.84 ; 2.23 ;-2.14, p=0.03<0.05)$. We state that independent variables (i.e., current assets ratio, equity-to-total liabilities ratio, inventory ratio) impact on company financial performance and, hence, we reject the null hypothesis and accept the alternative hypothesis. Therefore, an increase of 1000 units in RCA, REL and RI leads to an increase in ROS of 130 units and 340 units and to a decrease in ROS of 140 units. 


\subsection{Modeling Performance in the Leather Industry}

The econometric model estimating the return on assets sales ratio for the sample of enterprises operating in the leather industry is presented below (Table 6).

Table 6. The econometric model of return on assets for the SMEs in the leather industry.

\begin{tabular}{|c|c|c|c|c|}
\hline \multicolumn{5}{|c|}{$\begin{array}{c}\text { Dependent Variable: ROA } \\
\text { Method: Panel Least Squares } \\
\text { Sample: } 2004-2008 \\
\text { Cross-Sections Included: } 36 \\
\text { Total Panel (Balanced) Observations: } 180\end{array}$} \\
\hline \multicolumn{5}{|c|}{$\begin{array}{l}\text { White Diagonal Standard Errors and Covariance (d.f. Corrected) } \\
R O A=C(1)+C(2) \times R C A+C(3) \times R E L+C(4) \times R R+C(5) \times R I\end{array}$} \\
\hline & Coefficient & Std. Error & $t$-Statistic & Prob. \\
\hline$C(1)$ & 18.32 & 8.02 & 2.28 & 0.02 \\
\hline C(2) RCA & 0.12 & 0.04 & 2.93 & 0 \\
\hline C(3) REL & 0.17 & 0.04 & 4.02 & 0 \\
\hline$C(4) R R$ & -0.20 & 0.08 & -2.64 & 0.01 \\
\hline C(5) RI & -0.29 & 0.07 & -4.27 & 0 \\
\hline$R$-squared & 0.39 & \multicolumn{2}{|c|}{ Mean dependent variable } & 11.47 \\
\hline Adjusted $R$-squared & 0.38 & \multicolumn{2}{|c|}{ S.D. dependent variable } & 15.32 \\
\hline S.E. of regression & 12.08 & \multicolumn{2}{|c|}{ Akaike info criterion } & 7.85 \\
\hline Sum squared residual & $25,551.4$ & \multicolumn{2}{|c|}{ Schwarz criterion } & 7.94 \\
\hline Log likelihood & -701.4 & \multicolumn{2}{|c|}{ F-statistic } & 28.22 \\
\hline Durbin-Watson stat & 0.99 & \multicolumn{2}{|c|}{ Prob (F-statistic) } & 0 \\
\hline
\end{tabular}

The analysis indicates that the multiple regression model is significant with $R$-squared $=0.39$, meaning that $39 \%$ of the variation in the return on assets is explained by the independent variables, while $61 \%$ is explained by variables outside the model. Also, the F-statistic of 28.22 shows that the predictors are significantly related to the response variable. We observe that return on assets ratio is directly connected to current assets ratio (0.12), equity-to-total liabilities ratio (0.17) and is indirectly connected to receivables ratio $(-0.20)$ and inventory ratio $(-0.29)$.

The following econometric model estimates return on sales for the same sample of enterprises (Table 7).

Table 7. The econometric model of return on sales for SMEs in the leather industry.

\begin{tabular}{|c|c|c|c|c|}
\hline \multicolumn{5}{|c|}{ Dependent Variable: ROS } \\
\hline \multicolumn{5}{|c|}{ Method: Panel Least Squares } \\
\hline \multicolumn{5}{|c|}{ Sample: $2004-2008$} \\
\hline \multicolumn{5}{|c|}{ Cross-Sections Included: 36} \\
\hline \multicolumn{5}{|c|}{ Total Panel (Balanced) Observations: 180} \\
\hline \multicolumn{5}{|c|}{$\begin{array}{l}\text { White Diagonal Standard Errors and Covariance (d.f. Corrected) } \\
\quad R O S=C(1)+C(2) \times R E L+C(3) \times R D E+C(4) \times R I\end{array}$} \\
\hline & Coefficient & Std. Error & $t$-Statistic & Prob. \\
\hline $\mathrm{C}(1)$ & 6.43 & 1.94 & 3.32 & 0 \\
\hline C(2) REL & 0.13 & 0.03 & 4.29 & 0 \\
\hline C(3) RDE & 0 & $4.64 \times 10^{-5}$ & -2.24 & 0.03 \\
\hline C(4) RI & -0.06 & 0.03 & -2.07 & 0.04 \\
\hline$R$-squared & 0.21 & \multicolumn{2}{|c|}{ Mean dependent variable } & 8.58 \\
\hline Adjusted $R$-squared & 0.20 & \multicolumn{2}{|c|}{ S.D. dependent variable } & 10.21 \\
\hline S.E. of regression & 9.15 & \multicolumn{2}{|c|}{ Akaike info criterion } & 7.29 \\
\hline Sum squared residual & 14722.53 & \multicolumn{2}{|c|}{ Schwarz criterion } & 7.36 \\
\hline Log likelihood & -651.78 & \multicolumn{2}{|c|}{$F$-statistic } & 15.66 \\
\hline Durbin-Watson stat & 0.93 & \multicolumn{2}{|c|}{ Prob (F-statistic) } & 0 \\
\hline
\end{tabular}


The results indicate an average to low adjusted $R$-squared (0.2). The 15.66 value of $F$-statistic is average and shows that the predictor variables are significantly related to the dependent variable. We observe that, in this case, the return on sales for the analyzed SMEs is indirectly connected to the inventory ratio: ROS decreases with 60 units when RI increases with 1000 units. On the other hand, the return on sales ratio depends on the equity-to-total liabilities ratio. An increase of 1000 units in equity-to-total liabilities ratio (REL) leads to an increase of 13 units in ROS.

\subsection{Modeling Performance in the IT Industry}

The SME performance in the IT industry depends on the same predicting variables presented above. The first model features the estimation of the return on assets ratio (Table 8).

Table 8. The econometric model of return on assets for SMEs in the IT industry.

\begin{tabular}{|c|c|c|c|c|}
\hline \multicolumn{5}{|c|}{$\begin{array}{c}\text { Dependent Variable: ROA } \\
\text { Method: Panel Least Squares } \\
\text { Sample: } 2004-2008 \\
\text { Cross-Sections Included: } 346 \\
\text { Total Panel (Balanced) Observations: } 1730\end{array}$} \\
\hline \multicolumn{5}{|c|}{$\begin{array}{l}\text { White Diagonal Standard Errors and Covariance (d.f. Corrected) } \\
R O A=C(1)+C(2) \times R C A+C(3) \times R E L+C(4) \times R R+C(5) \times R I\end{array}$} \\
\hline & Coefficient & Std. Error & $t$-Statistic & Prob. \\
\hline $\mathrm{C}(1)$ & 11.82 & 2.15 & 5.51 & 0 \\
\hline C(2) RCA & 0.17 & 0.04 & 4.75 & 0 \\
\hline C(3) REL & 0.35 & 0.04 & 9.24 & 0 \\
\hline $\mathrm{C}(4) \mathrm{RR}$ & -0.10 & 0.01 & -7.67 & 0 \\
\hline C(5) RI & -0.20 & 0.02 & -9.73 & 0 \\
\hline$R$-squared & 0.27 & \multicolumn{2}{|c|}{ Mean dependent variable } & 22.44 \\
\hline Adjusted $R$-squared & 0.27 & \multicolumn{2}{|c|}{ S.D. dependent variable } & 17.73 \\
\hline S.E. of regression & 15.2 & \multicolumn{2}{|c|}{ Akaike info criterion } & 8.28 \\
\hline Sum squared residual & 398582.1 & \multicolumn{2}{|c|}{ Schwarz criterion } & 8.3 \\
\hline Log likelihood & -7160.18 & \multicolumn{2}{|c|}{$F$-statistic } & 157.03 \\
\hline Durbin-Watson stat & 0.91 & \multicolumn{2}{|c|}{ Prob (F-statistic) } & 0 \\
\hline
\end{tabular}

Results indicate an average value of adjusted $R$-squared (0.27) and a high value for F-statistic (157.03), which means that the predictor variables are significantly related to the response variable. We notice that for SMEs operating in the IT industry, the return on assets ratio is directly influenced by the current assets ratio (0.17) and the equity-to-total liabilities ratio (0.35). Moreover, we observe that an increase in RR and RI leads to a decrease in the dependent variable ROA with 0.10 and 0.20.

The estimation of return on sales for the IT industry is presented in the following (Table 9).

Table 9. The econometric model of return on sales for SMEs in the IT industry.

\begin{tabular}{|c|c|c|c|c|}
\hline \multicolumn{5}{|c|}{$\begin{array}{c}\text { Dependent Variable: ROS } \\
\text { Method: Panel Least Squares } \\
\text { Sample: } 2004-2008 \\
\text { Cross-Sections Included: } 346 \\
\text { Total Panel (Balanced) Observations: } 1730\end{array}$} \\
\hline \multicolumn{5}{|c|}{$\begin{array}{l}\text { White Diagonal Standard Errors and Covariance (d.f. Corrected) } \\
\qquad \mathrm{ROS}=\mathrm{C}(1)+C(2) \times \mathrm{RCA}+\mathrm{C}(3) \times \mathrm{REL}+\mathrm{C}(4) \times \mathrm{RI}\end{array}$} \\
\hline & Coefficient & Std. Error & $t$-Statistic & Prob. \\
\hline$C(1)$ & 3.66 & 2.27 & 1.61 & 0.11 \\
\hline C(2) RCA & 0.43 & 0.05 & 9.04 & 0 \\
\hline C(3) REL & 0.39 & 0.04 & 10.44 & 0 \\
\hline C(4) RI & -0.35 & 0.02 & -14.21 & 0 \\
\hline$R$-squared & 0.22 & \multicolumn{2}{|c|}{ Mean dependent variable } & 28.4 \\
\hline Adjusted $R$-squared & 0.22 & \multicolumn{2}{|c|}{ S.D. dependent variable } & 25.66 \\
\hline S.E. of regression & 22.69 & \multicolumn{2}{|c|}{ Akaike info criterion } & 9.08 \\
\hline Sum squared residual & $888,987.9$ & \multicolumn{2}{|c|}{ Schwarz criterion } & 9.1 \\
\hline Log likelihood & -7854.06 & \multicolumn{2}{|c|}{ F-statistic } & 161.53 \\
\hline Durbin-Watson stat & 0.76 & \multicolumn{2}{|c|}{ Prob (F-statistic) } & 0 \\
\hline
\end{tabular}


The analysis indicates an adjusted $R$-squared of average to low value (0.22) and a high $F$-statistic (161.53), which means that the predictors are significantly related to the response variable. We notice that, in this case, the return on sales is directly influenced by current assets ratio (RCA) and equity-to-total liabilities ratio (REL). Moreover, an increase in inventory ratio of 1000 units produces a decrease of 350 units in ROS.

\subsection{Modeling Performance in the Textile Industry}

The econometric analysis of performance in the textile industry is reflected by the return on assets ratio and the return on sales ratio (Table 10).

Table 10. The econometric model of return on assets for SMEs in the textile industry (with RCA as control variable).

\begin{tabular}{|c|c|c|c|c|}
\hline \multicolumn{5}{|c|}{$\begin{array}{l}\text { Dependent Variable: ROA } \\
\text { Method: Panel Least Squares } \\
\text { Sample: 2004-2008 } \\
\text { Cross-Sections Included: } 37 \\
1 \text { Panel (Balanced) Observations: } 185\end{array}$} \\
\hline \multicolumn{5}{|c|}{$\begin{array}{l}\text { White Diagonal Standard Errors and Covariance (d.f. Corrected) } \\
\qquad \mathrm{ROA}=\mathrm{C}(1) \times \mathrm{RCA}+\mathrm{C}(2) \times \mathrm{RDA}+\mathrm{C}(3) \times \mathrm{RI}\end{array}$} \\
\hline & Coefficient & Std. Error & $t$-Statistic & Prob. \\
\hline C(1) RCA & 0.28 & 0.06 & 4.36 & 0 \\
\hline$C(2)$ RDA & -0.07 & 0.03 & -2.02 & 0.05 \\
\hline C(3) RI & -0.05 & 0.02 & -2.14 & 0.03 \\
\hline$R$-squared & 0.16 & \multicolumn{2}{|c|}{ Mean dependent variable } & 6.02 \\
\hline Adjusted $R$-squared & 0.15 & \multicolumn{2}{|c|}{ S.D. dependent variable } & 7.76 \\
\hline S.E. of regression & 7.16 & \multicolumn{2}{|c|}{ Akaike info criterion } & 6.8 \\
\hline Sum squared residual & 9276.12 & \multicolumn{2}{|c|}{ Schwarz criterion } & 6.87 \\
\hline Log likelihood & -624.63 & \multicolumn{2}{|c|}{ F-statistic } & 11.8 \\
\hline Durbin-Watson stat & 0.85 & \multicolumn{2}{|c|}{ Prob (F-statistic) } & 0 \\
\hline
\end{tabular}

Results indicate a lower adjusted $R$-squared (0.15) and an average $F$-statistic (11.8), which show that the predictor variables are significantly related to the response variable. In this industry, the return on assets ratio positively depends on the return on current assets (RCA) and negatively depends on the total debt-to-assets ratio (RDA) and the inventory ratio (RI). Namely, an increase in RDA and RI of 1000 units determines a decrease in ROA of 70 units and 50 units, respectively.

In the following, we present the econometric model estimating return on assets for the sample of SMEs operating in the textile industry, when taking into account equity-to-total liabilities ratio (REL) and total debt-to-assets ratio (RDA).

The analyses reveal a lower adjusted $R$-squared (0.15) and an average $F$-statistic (12.85), showing that the predictor variables are significantly related to the response variable. As can be seen from Table 11, when REL, RDA and RI increase with 1000 units, ROA decreases with 250 units, 320 units and 60 units, respectively.

We also present below the econometric model estimating return on sales for the SME sample in the textile industry (Table 12).

Results indicate a lower adjusted $R$-squared (0.11) and an average $F$-statistic (8.9), which shows that the predictor variables are significantly related to the response variable. We also notice that there are no similarities between econometric models corresponding to the return on sales ratio and the ones corresponding to return on assets ratio determined for these Romanian SMEs. In this case, return on sales is indirectly connected to receivables ratio (RR) and inventory ratio (RI). Thus, an increase of 1000 units in the receivables ratio and the inventory ratio (RI) leads to a decrease in the ROS of 180 units and 150 units, respectively. 
Table 11. The econometric model of return on assets ratio for SMEs in the textile industry (with REL as control variable).

\begin{tabular}{|c|c|c|c|c|}
\hline \multicolumn{5}{|c|}{$\begin{array}{l}\text { Dependent Variable: ROA } \\
\text { Method: Panel Least Squares } \\
\text { Sample: 2004-2008 } \\
\text { Cross-Sections Included: } 37 \\
\text { otal Panel (Balanced) Observations: } 185\end{array}$} \\
\hline \multicolumn{5}{|c|}{$\begin{array}{l}\text { White Diagonal Standard Errors And Covariance (D.F. Corrected) } \\
\quad R O A=C(1)+C(2) \times R E L+C(3) \times R D A+C(4) \times R I\end{array}$} \\
\hline & Coefficient & Std. Error & $t$-Statistic & Prob. \\
\hline$C(1)$ & 26.98 & 4.59 & 5.87 & 0 \\
\hline C(2) REL & -0.25 & 0.05 & -4.96 & 0 \\
\hline C(3) RDA & -0.32 & 0.07 & -4.82 & 0 \\
\hline C(4) RI & -0.06 & 0.02 & -2.49 & 0.01 \\
\hline$R$-squared & 0.18 & \multicolumn{2}{|c|}{ Mean dependent variable } & 6.02 \\
\hline Adjusted $R$-squared & 0.16 & \multicolumn{2}{|c|}{ S.D. dependent variable } & 7.76 \\
\hline S.E. of regression & 7.11 & \multicolumn{2}{|c|}{ Akaike info criterion } & 6.78 \\
\hline Sum squared residual & 9143.93 & \multicolumn{2}{|c|}{ Schwarz criterion } & 6.85 \\
\hline Log likelihood & -623.3 & \multicolumn{2}{|c|}{ F-statistic } & 12.85 \\
\hline Durbin-Watson stat & 0.86 & \multicolumn{2}{|c|}{ Prob (F-statistic) } & 0 \\
\hline
\end{tabular}

Table 12. The econometric model of return on sales for SMEs in the textile industry.

\begin{tabular}{|c|c|c|c|c|}
\hline \multicolumn{5}{|c|}{$\begin{array}{c}\text { Dependent Variable: ROS } \\
\text { Method: Panel Least Squares } \\
\text { Sample: } 2004-2008 \\
\text { Cross-Sections Included: } 37 \\
\text { Total Panel (Balanced) Observations: } 185\end{array}$} \\
\hline \multicolumn{5}{|c|}{$\mathrm{ROS}=\mathrm{C}(1)+\mathrm{C}(2) \times \mathrm{RR}+\mathrm{C}(3) \times \mathrm{RI}$} \\
\hline & Coefficient & Std. Error & $t$-Statistic & Prob. \\
\hline$C(1)$ & 22.7 & 3.05 & 7.44 & 0 \\
\hline $\mathrm{C}(2) \mathrm{RR}$ & -0.18 & 0.04 & -4.34 & 0 \\
\hline C(3) RI & -0.15 & 0.04 & -3.81 & 0 \\
\hline$R$-squared & 0.13 & \multicolumn{2}{|c|}{ Mean dependent variable } & 9.67 \\
\hline Adjusted $R$-squared & 0.11 & \multicolumn{2}{|c|}{ S.D. dependent variable } & 11.92 \\
\hline S.E. of regression & 11.22 & \multicolumn{2}{|c|}{ Akaike info criterion } & 7.69 \\
\hline Sum squared residual & $22,768.35$ & \multicolumn{2}{|c|}{ Schwarz criterion } & 7.76 \\
\hline Log likelihood & -707.68 & \multicolumn{2}{|c|}{$F$-statistic } & 8.9 \\
\hline Durbin-Watson stat & 1.06 & \multicolumn{2}{|c|}{ Prob (F-statistic) } & 0 \\
\hline
\end{tabular}

\section{Conclusions}

In the present study conducted on 1233 SMEs from five economic sectors, we tackled the characteristics of the competitive business environment in Romania. In this regard, we built econometric models estimating return on assets and return on sales. As a result, we noticed that not all seven structure rates of assets and liabilities influenced the two performance ratios, i.e., return on assets and return on sales. In the case of return on assets, the independent variables that influenced performance in all econometric models were current assets ratio and inventory ratio in all models and equity-to-total liabilities ratio in $80 \%$ of the models. The other rates influence return on assets in a percentage of $40 \%$ each, namely: receivables ratio and total debt-to-assets ratio. We also notice that assets ratios have the highest influence on performance evaluation, namely: inventory ratio in all models and current assets ratio in $87.5 \%$ of the models. In addition, liabilities ratios influence 
performance as follows: equity-to-total liabilities ratio in $80 \%$ of the econometric models and total debt-to-assets ratio in 35\% of the econometric models.

Most firms have a large amount of cash invested in working capital. Therefore, it can be expected that the way in which working capital is managed will have a significant impact on company profitability. Shin and Soenen [39] report a strong negative relationship between cash conversion cycle and corporate profitability for a large sample of listed American firms, analyzed over the period 1975-1994. In our paper, we find a significant negative relationship between return on assets and return on sales, on one side, and receivables ratio and inventory ratio, on the other side. We also find a significant positive relationship between performance, i.e., ROA, ROS and equity-to-total liabilities. This means that managers have to decrease inventories and receivables in order to increase both the efficiency of asset use and sales. At the same time, managers have to permanently analyze whether clients meet the payment deadlines and whether the ratio computed as the number of days of accounts receivable to the number of days of accounts payable is constantly below the value of 1 . Otherwise, managers have to renegotiate payment deadlines with their customers and suppliers, i.e., the customers' payment deadlines have to be shorter than the suppliers' payment deadlines. Moreover, we believe that an increase in inventories and accounts receivables positively influence financial performance if their turnover accelerates from one period to another, i.e., if their reflection in the sales accelerates. From the standpoint of the horizontal analysis (based on computing ratios by using financial data from two different periods), an increase in inventories and accounts receivable is beneficial to the extent that it generates their turnover acceleration, which is mirrored in the shortening of the cash conversion cycle and in the release of monetary funds available for a new business cycle. These results suggest that managers can increase SME performance by reducing the number of days of accounts receivable and inventories to a reasonable minimum. The negative relation between accounts receivables and profitability is consistent with the view that less profitable companies wait longer to cash in their invoices. At the same time, SME owners have to increase social capital in order to develop businesses in the future and to compensate the temporary shortage of cash generated by smaller values of inventory turnover and receivables turnover. Due to the fact that a slowing inventory turnover means monetary funds tied up in raw materials, merchandise, work in progress, finished goods, in order to restart a production cycle one needs additional monetary funds, as such funds are to be used to pay employees, suppliers, taxes, etc. In this regard, there are two ways of obtaining funds: bank loans and equity increase. In our view, equity increase is a less costly way, because its cost is much lower than the interest on the banking market. When increasing equity, the financial effort of the company for covering additional financial costs diminishes.

The results obtained through analyzing data from 1233 SMEs support the indirect connection between performance (ROA, ROS), receivables ratio and inventory ratio, also reported in the literature by Moss and Stine (1993), Soenen (1993), Nobanee et al. (2004), Ebben and Johnson (2004), Bou and Sattora (2010), Baños-Caballero et al. (2012), Knauer and Wöhrmann (2013), Singhania et al. (2014), Yasir et al. (2014), Muscettola (2014), Öner (2016), Andone and Gaban (2016), Otuya and Eginiwin (2017). On the other hand, the current study revealed a direct connection between performance (ROA, ROS), current assets ratio and equity-to-total liabilities ratio, filling the gap in the literature developed on SME performance analysis. Moreover, the current study showed that, in the case of SMEs operating in the pharmaceutical industry, the fixed asset ratio has a significant influence on return on sales, thus emphasizing the importance of refurbishing for sales dynamics. The pharmaceutical industry is under continuous development. Diversifying medicine types involves introducing in the manufacturing process new types of medicines related to new diseases previously discovered. This translates into the need of using recently developed technologies and equipment, which generally have high costs. These costs are mirrored in the sale price of medicines, which at first can be quite high, thus contributing to the sales growth. However, after a while, as medicines progress from the prototype stage to the mass production stage, the SMEs register an increase in sales volume, even though the unit price decreases. 
Regarding the limits of the study, our research focused on 1233 Romanian SMEs from five sectors, during a five-year period. Secondly, we estimated linear models for return on assets and return on sales. Thirdly, our study did not take into account accounts payable in order to analyze the degree in which its increase would determine a performance variation. Therefore, more empirical investigations need to be conducted on this topic by replicating the current study and by including more specific variables to control for the effect of other equilibrium factors on SME performance. As this study focuses on the time frame 2004-2008, future studies could consider longer periods and could explore the appropriate manners for adjusting balance sheet ratios during financial crisis in order to increase profitability.

In terms of avenues for future research, these models could be applied in SME samples from the European Union, the US, China or Japan. Furthermore, in order to estimate econometric models in the case of SMEs, one could consider other dependent variables related to performance, such as return on equity, profit margin, earnings-per-share ratio, net worth ratio or return on investment.

Acknowledgments: We are grateful to two anonymous reviewers for their helpful suggestions.

Author Contributions: M.E. collected the data; B.I. analyzed the data; B.I., M.I.D., M.E., C.S. and B.L. wrote the paper.

Conflicts of Interest: The authors declare no conflict of interest.

\section{References}

1. Lu, J.W.; Beamish, P.W. SME Internationalization and Performance: Growth vs. Profitability. J. Int. Entrep. 2006, 4, 27-48. [CrossRef]

2. Salman, A.K.; Yazdanfar, D. Profitability in Swedish Micro Firms: A Quantile Regression Approach. Int. Bus. Res. 2012, 5, 94-106. [CrossRef]

3. McMahon, R.G.P. Business Growth and Performance and the Financial Reporting Practices of Australian Manufacturing SMEs. J. Small Bus. Manag. 2001, 39, 152-164. [CrossRef]

4. Farah, M.; Supartika, N. Factors Affecting Profitability of Small Medium Enterprises (SMEs) Firm Listed in Indonesia Stock Exchange. J. Econ. Bus. Manag. 2016, 4, 132-137.

5. Mikkola, J.; Rummukainen, A.; Penttinen, M. Profitability, Liquidity and Solvency of Wood Harvesting Contractors in Finland. Small Scale For. 2011, 10, 211-229.

6. Gedajlovic, E.; Shapiro, D.M.; Buduru, B. Financial Ownership, Diversification and Firm Profitability in Japan. J. Manag. Gov. 2003, 7, 315-335. [CrossRef]

7. Goddard, J.; Tavakoli, M.; Wilson, J.O.S. Determinants of Profitability in European Manufacturing and Services: Evidence from a Dynamic Panel Model. Appl. Financ. Econ. 2005, 15, 1269-1282. [CrossRef]

8. Fitzsimmons, J.R.; Steffens, P.R.; Douglas, E.J. Growth and Profitability in Small and Medium Sized Australian Firms; AGSE Entrepreneurship Exchange: Melbourne, Australia, 2005.

9. Knauer, T.; Wöhrmann, A. Working Capital Management and Firm Profitability. J. Manag. Control 2013, 24, 77-87. [CrossRef]

10. Singhania, M.; Sharma, N.; Rohit, Y.J. Working Capital Management and Profitability: Evidence from Indian Manufacturing Companies. Decis. J. 2014, 41, 313-326. [CrossRef]

11. Yasir, M.; Majid, A.; Yousaf, Z. Cash Conversion Cycle and Its Impact upon Firm Performance: An Evidence from Cement Industry of Pakistan. Glob. Bus. Manag. Res. 2014, 6, 139-149.

12. Nobanee, H.; Abdullatif, M.; AlHajjar, M. Cash Conversion Cycle and Firm's Performance of Japanese Firms. Asian Rev. Account. 2004, 19, 147-156. [CrossRef]

13. Ebben, J.J.; Johnson, A.C. Cash Conversion Cycle Management in Small Firms: Relationships with Liquidity, Invested Capital, and Firm Performance. J. Small Bus. Entrep. 2004, 24, 380-396. [CrossRef]

14. Moss, J.D.; Stine, B. Cash Conversion Cycle and Firm Size: A Study of Retail Firms. Manag. Financ. 1993, 19, 25-34. [CrossRef]

15. Soenen, L. Cash Conversion Cycle and Corporate Profitability. J. Cash Manag. 1993, 13, 34-53.

16. Muscettola, M. Cash Conversion Cycle and Firm's Profitability: An Empirical Analysis on a Sample of 4226 Manufacturing SMEs of Italy. Int. J. Bus. Manag. 2014, 9, 25-35. [CrossRef]

17. Baños-Caballero, S.; García-Teruel, P.J.; Martínez-Solano, P. How Does Working Capital Management Affect the Profitability of Spanish SMEs? Small Bus. Econ. 2012, 39, 517-529. [CrossRef] 
18. Öner, M. The Impact of Working Capital Management on Firm Profitability: Empirical Evidence from Borsa Istanbul. Res. J. Polit. Econ. Manag. 2016, 4, 63-79.

19. Otuya, S.; Eginiwin, E.J. Inventory Management and SMEs Profitability. A Study of Furniture Manufacturing, Wholesale and Eatery Industry in Delta State. Niger. J. Financ. Account. 2017, 5, 75-79.

20. Bou, J.C.; Satorra, A. A Multigroup Structural Equation Approach: A Demonstration by Testing Variation of Firm Profitability across EU Samples. Organ. Res. Methods 2010, 13, 738-766. [CrossRef]

21. Andone, D.; Gaban, L. The Cash Conversion Cycle in Romanian Companies. Ann. Constantin Brancusi Univ. Târgu Jiu Econ. Ser. 2016, 1, 128-137.

22. Major, I. Technical Efficiency, Allocative Efficiency and Profitability in Hungarian Small and Medium-Sized Enterprises: A Model with Frontier Functions. Eur. Asia Stud. 2008, 60, 1371-1396. [CrossRef]

23. Bezuidenhout, A.; Mlambo, C.; Hamman, W.D. Investigating Causality between Cash Flow and Profitability: An Econometrics Approach. Meditari Account. Res. 2008, 16, 27-41. [CrossRef]

24. Martínez-Sola, C.; García-Teruel, P.J.; Martínez-Solano, P. Trade Credit and SME Profitability. Small Bus. Econ. 2014, 42, 561-577. [CrossRef]

25. Gaban, L. Cash Flows in Romanian Small and Medium Enterprises. Ann. Constantin Brancusi Univ. Târgu Jiu Econ. Ser. 2016, 4, 46-52.

26. Isberg, S.; Pitta, D. Using Financial Analysis to Assess Brand Equity. J. Prod. Brand Manag. 2013, 22 , 65-78. [CrossRef]

27. Abeywardhana, D.K.Y. Capital Structure and Profitability: An Empirical Analysis of SMEs in the UK. J. Emerg. Issues Econ. Financ. Bank. 2015, 4, 1661-1675.

28. Csegedi, S.; Batrancea, L.M.; Moscviciov, A. A Statistical Study on the IT Romanian Companies Performance. J. Econ.-Financ. Theory Pract. 2012, 4, 195-198.

29. Moscviciov, A.; Batrancea, L.M.; Nichita, R.A. A System of Assessing the Performance of Romanian IT Companies. J. Econ.-Financ. Theory Pract. 2010, 6, 122-126.

30. Gaban, L. Financial Policies in the Romanian SMEs. “Ovidius" Univ. Ann. Econ. Ser. 2015, XV, 434-438.

31. Serrasqueiro, Z.S.; Maçãs Nunes, P. Performance and Size: Empirical Evidence from Portuguese SMEs. Small Bus. Econ. 2008, 31, 195-217. [CrossRef]

32. Fu, G.; Fu, W.; Liu, D. Empirical Study on Financial Risk Factors: Capital Structure, Operation Ability, Profitability, and Solvency Evidence from Listed Companies in China. J. Bus. Manag. Econ. 2012, 3, 173-178.

33. Olutunla, G.T.; Obamuyi, T.M. An Empirical Analysis of Factors Associated with the Profitability of Small and Medium-Enterprises in Nigeria. Afr. J. Bus. Manag. 2008, 2, 195-200.

34. Olufunso, F.O.; Herbst, G.; Roberts-Lombard, M. An Investigation into the Impact of the Usage of Debt on the Profitability of Small and Medium Enterprises in the Buffalo City Municipality, South Africa. Afr. J. Bus. Manag. 2010, 4, 373-381.

35. Holz, C.A. The Impact of the Liability-Asset Ratio on Profitability in China's Industrial State-owned Enterprises. China Econ. Rev. 2002, 13, 1-26. [CrossRef]

36. Žager, K.; Sačer, I.M.; Dečman, N. Financial Ratios as an Evaluation Instrument of Business Quality in Small and Medium-sized Enterprises. Int. J. Manag. Cases 2012, 14, 373-385.

37. Malhotra, R.; Malhotra, D.K.; Russel, P.S. Using Data Envelopment Analysis to Rate Bonds. J. Bus. Econ. Stud. 2010, 16, 58-76.

38. Lu, F.; Song, G.; Tang, J.; Zhao, H.; Liu, L. Profitability of China's Industrial Firms (1978-2006). China Econ. J. 2008, 1, 1-31. [CrossRef]

39. Shin, H.H.; Soenen, L. Efficiency of Working Capital and Corporate Profitability. Financ. Pract. Educ. 1998, 8 , $37-45$.

(C) 2018 by the authors. Licensee MDPI, Basel, Switzerland. This article is an open access article distributed under the terms and conditions of the Creative Commons Attribution (CC BY) license (http:/ / creativecommons.org/licenses/by/4.0/). 